\title{
A Genotyping and Phenotyping Study Concerning the Possible Effects of Some Inflammatory Cytokine Gene Polymorphisms on the Development of Coal Workers' Pneumoconiosis
}

\author{
Ilker Ates ${ }^{1 *}$, Asuman Karakaya ${ }^{1}$, Sinan H. Suzen ${ }^{1}$, Berran Yucesoy ${ }^{2}$ \\ ${ }^{1}$ Department of Toxicology, Faculty of Pharmacy, Ankara University, 06100 Tandogan, Ankara, Turkey \\ ${ }^{2}$ Health Effects Laboratory Division, CDC/NIOSH, Morgantown, WV, USA
}

Received: December 31, 2016; Accepted: January 09, 2017; Published: February 10, 2017

*Corresponding author: Ilker ATES, Department of Toxicology, Faculty of Pharmacy, Ankara University, 06100 Tandogan, Ankara, Turkey,

Tel:+90 5442340247; E-mail: ilkerates976@gmail.com

\begin{abstract}
Cytokines are important for playing a major role in several inflammatory reactions resulting in development of several diseases as well as Coal Worker's Pneumoconiosis (CWP). Coal dust exposure stimulates inflammatory response leading to enhanced cytokine release from monocytes such as TNF-alpha and IL1. These released cytokines are the key points in the pathogenesis of CWP. The present study aimed to seek the cytokine gene profiles of Turkish coal workers by genotyping and phenotyping analysis of important CWP-related proinflammatory cytokines; TNF-alpha, IL1-alpha and IL1-beta. According to the genotyping results, TNFA -238 gene polymorphism was appeared to be a risk factor in development of CWP (OR=3.79) and regarding to the phenotyping analysis, both TNF-alpha and IL1 cytokine releases from the monocytes in CWP patients were enhanced significantly compared to the healthy workers. Therewithal, LPS and coal dust stimulated TNF-alpha release were higher significantly in allele 2 carriers than allele 1 carriers in both of the groups. These data propose that coal dust-induced TNF-alpha release from monocytes may be a valuable biomarker of CWP.
\end{abstract}

\section{Introduction}

Similarly to several developing countries, coal mining is still important in Turkey contrary to the shutdown of many coal mines in developed countries. Due to the official data of the Turkey Hard Coal Enterprise, in 2015 there were 17,014 registered coal miners in whole country (Turkey Hard Coal Enterprise, 2016).

Coal worker's pneumoconiosis (CWP) is an occupational lung disease signalized by fibrotic nodular lesions following the inhalation of coal dust. CWP is defined as the accumulation of the coal dust in lungs and the tissue's reaction to its presence (Morgan and Seaton, 1975). Cytokines are crucial mediators of toxic and pathogenic effects seen in mineral dust exposure of humans and playing a major role in several important biological processes particularly in inflammation and immune response (Schins and Borm, 1999). TNF-alpha and IL1 cytokines are called as proin- flammatory cytokines and their key roles in CWP and silicosis development are endorsed by plenty of experimental researches (Zhai et al., 1998; Corbett et al., 2002; Nadif et al., 2003; Fan et al., 2010; Lee et al., 2010; Li et al., 2011, Wang et al., 2012; Kurniawidjaja 2014; Jiang PR et al., 2015). Latest studies have shown an association of TNF alpha gene polymorphisms with sensitivity to lung diseases including asthma, chronic bronchitis and fibrosing alveolitis (Huang et al., 1997; Whyte et al., 2000, Witte et al., 2002; Mukhopadhyay S et al., 2006; Yang et al., 2015; Makamure et al., 2016).

Because cytokines are key regulators of homeostatic mechanisms, possible variations in their levels or their structures may be related with the disease process (Ollier, 2004). The polymorphism commonly originates as a Single Nucleotide Polymorphism (SNP) in the network of cytokines and a vast number of SNPs have been recognized in regulatory regions of genes acting on their synthesis or degradation rates. Epidemiological researches have indicated that both pro- and anti-inflammatory cytokine SNPs are related with immune-mediated diseases (Zhai et al., 1998; Francis et al., 1999; Franceschi et al., 2001; Yucesoy et al., 2001; Kim et al., 2002; Ohtsuka et al., 2002; Yucesoy et al., 2005; Jonth et al., 2007; Fan et al., 2010; Li et al., 2011; Wang et al., 2012; Makamure et al., 2016).

Subsequent to coal dust exposure, lung tissue responds by starting three types of phenomena: an accumulation and activation of inflammatory cells in lower respiratory tract, fibroblast proliferation and an increased synthesis of extracellular matrix components (Vanhee et al., 1995). Macrophage-derived cytokines are the key points in coal dust inflammation. Presence of persistent stimulus and chronic release of cytokines may conclude in autoimmune and inflammatory diseases as well as CWP or silicosis. Recent records have displayed that following the coal dust exposure of alveolar macrophages, a significant release of TNF-alpha and IL1 from blood monocytes occurs (Lasalle et al., 1990; Jorna et al., 1994; Zhai et al., 1998; Kim et al., 1999; Borm 
and Schins, 2001; Wang et al., 2005; Zhang et al., 2015).

Several researches have pointed out that TNF-alpha release from blood monocytes differentiates coal workers with respiratory and pulmonary effects of coal dust (Jorna et al., 1994; Zhai et al., 1998). According to the data of these studies, release of monocytes TNF-alpha is a valid means to CWP prognosis beneath history and X-rays when carefully applied. Comprehension of the underlying mechanisms of the CWP aetiology was fundamental in offering numerous biomarkers evaluated to appraise the effects following exposure to coal dust. Human studies exhibited some of these offered biomarkers for CWP including TNF-alpha released from monocytes and TNF-alpha polymorphism (blood cellular DNA) and also they were defined as biomarkers of sensitivity (Gulumian et al., 2006).

In this study, we aimed to follow two assumptions: First, CWPassociated pro-inflammatory cytokines (TNF-alpha, IL1-alpha and IL1-beta) gene polymorphisms related with CWP in a group of Turkish coal workers. Second, these gene polymorphisms have an important role on the release of these cytokines from blood monocytes due to the coal dust exposure in homozygous and minor variant allele carriers. To check over these assumptions; we gathered coal workers having a heavy dust exposure background and searched the stated cytokines releases from blood monocytes by genotyping and phenotyping analyses.

\section{Materials and Methods}

All the individuals were gathered from Kozlu/Zonguldak region of Turkey where coal is densely mined. For genotyping analyses, subjects were categorized into two groups: 67 retired coal worker with CWP as patients and 92 workers without any CWP evidence as controls. All active coal workers were chosen from the mining part of the mine (except the coal face or stope) having a mean coal dust exposure $0.07-1.25 \mathrm{mg} / \mathrm{m}^{3}$ respirable coal dust fraction). Mean coal chemical properties of Kozlu mines were as follows: $55 \%$ carbon, $28 \%$ volatile substances, $10 \%$ ash, $7 \%$ moisture and also about $47 \%$ of the ash came out of crystalline silica. After defining the genotype profiles of the all individuals, their profiles were inspected cautiously for studied cytokine gene polymorphisms. Patients frequently (at least 3 of the 5 ) bearing $1 / 2+2 / 2$ or $2 / 2$ alleles $(n=19)$ and healthy workers frequently (at least 3 of the 5 ) bearing homozygous $1 / 1 \mathrm{al}$ lele $(n=19)$ a total of 38 subjects were chosen among the study groups to consider the possible effects of gene polymorphisms on the release of the studied cytokines from blood monocytes. All of the subjects belonging to study groups replied a brief questionnaire providing information about past medical and occupational background, smoking, lifestyle and drug usage. Informed consent was achieved from all individuals in consonant to the Helsinki declaration (1983) of the World Medical Association. We had approval of the Ankara University Faculty of Medicine Ethic Committee for this scientific research and posses informed consents of all persons involved in the study.

\section{DNA preparation and genotyping}

$10 \mathrm{ml}$ whole bloods of all studied individuals were collected by venipuncture in tubes containing heparin. Afterwards, DNA isolation were performed by Promega Wizard Genomic DNA Purification kit due to the manufacturer's instructions and all the DNA samples were stored at $-20^{\circ} \mathrm{C}$ till analyses. Genotyping of TNF-alpha -308G/A, TNF-alpha -238G/A, IL1-alpha +4845C/T and IL1-beta $+3953 \mathrm{C} / \mathrm{T}$ gene polymorphisms were carried out using a Polymerase Chain Reaction-Restriction Fragment Length Polymorphism (PCR-RFLP) method due to the formerly mentioned protocols with minor modifications from Ates et al., (2008). PCR reaction products were departed by gel electrophoresis on a $10 \%$ polyacrilamide-TBE gel at $200 \mathrm{~V}$ for $40 \mathrm{~min}$ and then viewed via an UV illumination following staining with ethidium bromide solution.

\section{Monocyte isolation and measurement of cytokine release}

The isolation of monocytes from the peripheral blood was performed due to the technique of Strober (1994). The cytokine release levels from adherent monocytes supernatants $\left(5 \times 10^{6}\right)$ were calculated by Enzyme-linked Immunosorbent Assay (ELISA) without a stimulant (spontaneous) or afterwards $18 \mathrm{~h}$ of incubation with coal dust $(5 \mathrm{mg} / \mathrm{ml})$ and LPS $(1000 \mathrm{ng} / \mathrm{ml})$ at $37^{\circ} \mathrm{C}$ and $5 \% \mathrm{CO}_{2}$.

\section{Statistical analysis}

For whole of the statistical analyses, we exerted the version no 15 of the SPPS programme (SPSS Inc., Chicago, IL, USA). Possible significant associations between polymorphic variants and disease situation were commentated by $\chi^{2}$ test and Fischer exact test where suitable. The $\chi^{2}$ test was performed to check against allele and genotype frequencies between controls and cases. Odds ratios (OR) and incorporated 95\% Confidence Intervals (CI) were evaluated by logistic regression. A p-value $<0.05$ was regarded as significant.

\section{Results}

(Table 1) demonstrates the demographic output of all the studied individuals. No interactions were obtained between the CWP and the parameters of age and smoking following the multiple linear regression method. On the other hand, work period was found to be associated with the development of the disease.

(Table 2) indicates the distribution of TNF-alpha and IL1 genotypes. Whole SNPs in both controls and cases were in the Hardy-Weinberg equilibrium. Entire risk of disease was significantly higher only with TNF-alpha $(-238)$ variant (OR= 3.79, 95\% CI: 1.37-10.46). In regards of TNF-alpha (-308) variant, an enhancement risk for CWP was observed however it was not significant $(\mathrm{OR}=1.37$ : 95\% CI, 0.73-2.58). No significant relationship was seen between neither the IL1-alpha nor IL1beta variants with CWP.

(Table 3) represents the allelic distribution of the group of CWP patients matched with controls. The development of the disease was ascended in allele 2 carriers than the ones hauling allele 1 . The basal, the LPS and the coal dust-caused cytokine release were seized up for appraising the in vitro cytokine release 
from the blood lymphocytes. As obviously seen from the data given in Table 4, there was a significant association between the patients hauling allele 2 compared to those of controls $(\mathrm{p}<0.05)$.

In (Table 4), TNF-alpha and IL1 cytokine releases from blood monocytes of controls and CWP patients were demonstrated. The release order of studied cytokines was as spontaneous $<$ coal dustinduced <LPS-induced. The release of these cytokines in CWP patients were significantly enhanced in contrast to the controls. Conversely, the coal dust-induced release of TNF-alpha in allele

Table 1: The demographic data of the subjects

\begin{tabular}{|c|c|c|}
\hline & $\begin{array}{l}\text { Control } \\
\text { group }\end{array}$ & $\begin{array}{l}\text { CWP } \\
\text { Patients }\end{array}$ \\
\hline No. of subjects & 92 & 67 \\
\hline $\begin{array}{l}\text { No. of subjects with simple } \\
\text { pneumoconiosis (SP) } \\
\text { No. of subjects with progressive } \\
\text { massive fibrosis (PMF) } \\
\text { Age }( \pm \text { S.E) }\end{array}$ & $\begin{array}{l}- \\
48.75 \pm 5.21\end{array}$ & $\begin{array}{l}41 \\
26 \\
58.60 \pm 4.41\end{array}$ \\
\hline Work period (year) ( \pm S.E) & $13.21 \pm 6.93^{\mathrm{a}}$ & $22.39 \pm 6.05$ \\
\hline \multicolumn{3}{|l|}{ Smoking status (\%) } \\
\hline $\begin{array}{l}\text { Yes } \\
\text { Ex-smoker } \\
\text { No }\end{array}$ & $\begin{array}{l}49(\% 53.3) \\
29(\% 31.5) \\
14(\% 15.2)\end{array}$ & $\begin{array}{l}46(\% 68.7) \\
21(\% 31.3)\end{array}$ \\
\hline
\end{tabular}

Table 2: The genotypic distribution of TNF-alpha and IL1.

\begin{tabular}{|c|c|c|c|c|}
\hline Genotypes & \multicolumn{2}{|c|}{ TNFA (-308) } & \multicolumn{2}{c|}{ TNFA (-238) } \\
\hline & $\begin{array}{c}\text { Control } \\
\text { n (\%) }\end{array}$ & $\begin{array}{c}\text { CWP } \\
\text { patients } \\
\text { n (\%) }\end{array}$ & $\begin{array}{c}\text { Control } \\
\text { n (\%) }\end{array}$ & $\begin{array}{c}\text { CWP patients } \\
\text { n (\%) }\end{array}$ \\
\hline $1 / 1$ alleles & $47(51.1)$ & $29(43.3)$ & $86(93.5)$ & $53(79.1)$ \\
\hline $1 / 2+2 / 2$ alleles & $45(48.9)$ & $38(56.7)$ & $6(6.5)$ & $14(20.9)$ \\
\hline $\mathrm{OR}^{*}(\mathrm{CI})$ & 1.00 & $\begin{array}{c}1.37(0.73- \\
2.58)\end{array}$ & 1.00 & $3.79(1.37-10.46)^{\mathrm{a}}$ \\
\hline & \multicolumn{2}{|c|}{ IL1A (+4845) } & & IL1B (+3953) \\
\hline $1 / 1$ alleles & $62(67.4)$ & $44(65.7)$ & $18(19.6)$ & $14(20.9)$ \\
\hline $1 / 2+2 / 2$ alleles & $30(32.6)$ & $23(34.3)$ & $74(80.4)$ & $53(79.1)$ \\
\hline $\mathrm{OR}^{*}(\mathrm{CI})$ & 1.00 & $\begin{array}{c}1.08(0.55- \\
2.10)\end{array}$ & 1.00 & $0.92(0.42-2.01)$ \\
\hline
\end{tabular}

a $P<0,001$ compared with controls, ${ }^{*}$ Odds ratios (OR) and associated $95 \%$ confidence intervals $(\mathrm{CI})$

Table 3: Allelic distribution of patient group matching with controls

\begin{tabular}{|c|c|c|c|c|}
\hline & $\begin{array}{c}\text { Control } \\
\text { group }\end{array}$ & $\begin{array}{c}\text { Allele Freq. } \\
(\%)\end{array}$ & $\begin{array}{c}\text { CWP } \\
\text { patients }\end{array}$ & Allele Freq. (\%) \\
\hline $\begin{array}{c}\text { Allele 1 } \\
\text { carriers* }\end{array}$ & 11 & 71.1 & 7 & 45.9 \\
\hline $\begin{array}{c}\text { Allele 2 } \\
\text { carriers* } \\
\text { Total }\end{array}$ & 8 & 28.9 & 12 & $54.1^{\text {a }}$ \\
\hline
\end{tabular}

${ }^{a}$ significantly different from the allele 2 carriers in control group, $\mathrm{p}<0.05$ * individuals bearing $1 / 1$ or $1 / 2$ were grouped as allele 1 carriers, patients bearing $1 / 2$ or $2 / 2$ were grouped as allele 2 carriers
Table 4: In vitro release of TNF-alpha from monocytes induced by LPS and coal dust among 19 healthy workers and 19 CWP patients

Monocyte TNF-alpha release $(\mathrm{ng} / \mathrm{ml})^{*}$

\begin{tabular}{|c|c|c|c|}
\hline & Unstimulated & $\begin{array}{l}\text { Coal dust (5 } \\
\mathrm{mg} / \mathrm{ml} \text { ) }\end{array}$ & $\begin{array}{l}\text { LPS (1.000 ng/ } \\
\mathrm{ml} \text { ) }\end{array}$ \\
\hline \multicolumn{4}{|l|}{ Healthy workers } \\
\hline $\begin{array}{l}\text { Allele } 1 \text { carriers } \\
(\mathrm{n}=11)\end{array}$ & $1.23(0.11)$ & 3.87 (1.55) & 4.75 (1.89) \\
\hline $\begin{array}{l}\text { Allele } 2 \text { carriers } \\
(\mathrm{n}=8)\end{array}$ & $1.26(0.14)$ & $5.52(1.97)^{a}$ & $8.04(2.26)^{b}$ \\
\hline \multicolumn{4}{|l|}{ CWP patients } \\
\hline $\begin{array}{l}\text { Allele } 1 \text { carriers } \\
(\mathrm{n}=7)\end{array}$ & $4.51(1.23)$ & $10.29(2.24)$ & 13.75 (4.77) \\
\hline $\begin{array}{l}\text { Allele } 2 \text { carriers } \\
(n=12)\end{array}$ & $4.97(1.44)$ & $13.52(3.85)^{a}$ & $21.84(5.11)^{b}$ \\
\hline
\end{tabular}

Monocyte IL1-alpha release $(\mathrm{ng} / \mathrm{ml})^{*}$

\begin{tabular}{|l|l|l|l|}
\hline Healthy workers & & & \\
\hline $\begin{array}{l}\text { Allele } 1 \text { carriers } \\
(\mathrm{n}=11)\end{array}$ & $0.41(0.19)$ & $1.17(0.57)$ & $2.09(1.42)$ \\
\hline $\begin{array}{l}\text { Allele 2 carriers } \\
(\mathrm{n}=8)\end{array}$ & $0.59(0.23)$ & $1.34(0.63)$ & $2.51(1.71)$ \\
\hline CWP patients & & & \\
\hline $\begin{array}{l}\text { Allele } 1 \text { carriers } \\
(\mathrm{n}=7)\end{array}$ & $2.51(1.12)$ & $5.62(1.79)$ & $7.81(2.87)$ \\
\hline $\begin{array}{l}\text { Allele 2 carriers } \\
(\mathrm{n}=12)\end{array}$ & $4.82(2.27)$ & $7.05(3.06)$ & $9.86(3.88)$ \\
\hline
\end{tabular}

Monocyte IL1-alpha release ( $\mathrm{ng} / \mathrm{ml})^{*}$

\begin{tabular}{|c|c|c|c|}
\hline Healthy workers & & & \\
\hline $\begin{array}{l}\text { Allele } 1 \text { carriers } \\
(n=11)\end{array}$ & $0.55(0.23)$ & $1.59(0.74)$ & $2.01(0.94)$ \\
\hline $\begin{array}{l}\text { Allele } 2 \text { carriers } \\
(\mathrm{n}=8)\end{array}$ & $0.89(0.51)$ & $1.80(0.97)$ & 2.73 (1.15) \\
\hline \multicolumn{4}{|l|}{ CWP patients } \\
\hline $\begin{array}{l}\text { Allele } 1 \text { carriers } \\
(\mathrm{n}=7)\end{array}$ & 3.25 (1.23) & $5.59(2.01)$ & $6.72(2.65)$ \\
\hline $\begin{array}{l}\text { Allele } 2 \text { carriers } \\
(\mathrm{n}=12)\end{array}$ & $\begin{array}{l}\text { Allele } 2 \text { carriers } \\
(\mathrm{n}=12)\end{array}$ & $7.49(2.63)$ & $8.73(3.23)$ \\
\hline
\end{tabular}

2 carriers was significantly increased compared to those hauling allele 1 in both study groups. In despite of an increase of the IL1 cytokines release in allele 2 carriers in all subjects, no significant distinction was observed. Smoking was also considered as a confounding factor but no relationship was found of the possible effects of smoking on the release of cytokines.

\section{Discussion}

In this research, we gathered a group of coal workers with CWP who had a common history to heavy dust exposure. According to the data, we sighted significantly higher allele frequencies of $-238 \mathrm{~A}$ in patients contrast to controls. Moreover, it seems that TNF-alpha is an important parameter in development of CWP more than IL1. TNF-alpha-238A variant should be kept in 
mind as a risk parameter in development of the disease and there is an enhancing effect of TNF-alpha cytokine gene polymorphism on release of it from the blood monocytes.

Even though its pathophysiological mechanisms have not been fully identified, coal dust has been known as the most important factor for the development of CWP. Chronic diseases induced by inflammation including CWP are multi-factorial ones directly affected by both genetic and environmental parameters. Polymorphisms such as genetic factors can switch the size or severity of the disease. In regards to this, SNPs are important affecting the amount of inflammatory cytokines which have been related with too many different chronic inflammatory and autoimmune diseases (Zhai et al., 1998; Franceschi et al., 2001; Yucesoy et al., 2001; Ates et al., 2008; Wang et al., 2012; Yang et al., 2015; Makamure et al., 2016).

TNF-alpha is an major cytokine relative to CWP's inflammatory and fibrotic processes (Schins and Borm, 1999). Variations at -238 and -308 have been suggested to be responsible for the modification of TNF-alpha production (Fan et al., 2010). A relationship between -308 variant and CWP in Europeans (Zhai et al., 1998), in South Africans (Corbett et al., 2002), in Japans (Wang et al., 2005) and in Chinese (Fan et al., 2010) has been observed. In these researches, the possible effect of TNF-alpha -238 variant was also studied and due do the data, only Corbett et al., (2002) and Ates et al., (2008) have obtained distinct relationship between this variant with the development of CWP. In respect to our research, according to the genotyping data, we found -238 variant to be a powerful risk factor for CWP. On the contrary, we observed an enhancement risk factor for -308 variant in patients compared to controls but it was not significant.

IL-1 is one of the most studied proinflammatory cytokines as similar as TNF-alpha. There are many researches related with the possible effects of IL1 gene polymorphisms on several pulmonary and autoimmune diseases except CWP. In our study, we did not observe any significant relationship with IL1-alpha variants and the development of CWP. For each polymorphism, the odds ratio of disease and associated 95\% confidence intervals for individuals carrying alleles 2 were reported for the CWP patients, using logistic regression models with adjustment for age, years of exposure and smoking.

Latest in vitro release researches have indicated that proinflammatory cytokine levels of TNF-alpha and IL1 were triggered in CWP (Schins and Borm, 1995; Zhai et al., 1998; Kim et al., 1999). According to our data, we found an enhanced release of TNF-alpha from blood monocytes after coal dust and LPS stimulation in contrast to spontaneous release in both controls and patients. The level of released TNF-alpha was significantly increased in allele 2 carriers than allele 1 hauliers. These results are alike to the data of Zhai and co-workers (1998) and Kim and co-workers (2002). On the other hand, even though there was a triggering effect in the release of IL1-alpha and IL1-beta, no significant differences were found between both allele 1 and 2 hauliers. It was obviously observed that in patients, the levels of cytokine release from monocytes were about 3-4 fold higher than controls. These findings indicate an association between coal dust exposure and cytokine releases in the development of CWP.

In this study, smoking did not point out any significant contribution to the development of CWP.

Due to the limited sample size of the studied groups, we need to comment these findings cautiously as precursors. Further researches performed with sufficient " $n$ " number are needed to verify these results.

In conclusion, due to our genotyping findings, TNFA -238 gene polymorphism was appeared to be a risk factor in development of CWP $(\mathrm{OR}=3.79)$ and regarding to the phenotyping analysis, both TNF-alpha and IL1 cytokine releases from the monocytes in CWP patients were enhanced significantly compared to the healthy workers. Therewithal, LPS and coal dust stimulated TNF-alpha release were higher significantly in allele 2 carriers than allele 1 carriers in both of the groups. These data propose that coal dust-induced TNF-alpha release from monocytes may be a valuable biomarker of CWP. Further intended comprehensive researches with a vast number of individuals should be performed to illuminate the underlying mechanisms and possible effects of these cytokine gene polymorphisms.

\section{Acknowledgements}

This study was supported by Research Fund of Ankara University

\section{References}

1. Ates I, Suzen HS, Yucesoy B, Tekin, IO, Karakaya A. Association of cytokine gene polymorphisms in CWP and its severity in Turkish coal workers. Am J Ind Med. 2008;51(10):741-747.

2. Borm PJA, Schins RPF: Genotype and phenotype in susceptibility to coal workers' pneumoconiosis. The use of cytokines in perspective. Eur Respir J. 2001;18:127-133.

3. Corbett EL, Mozzato-Chamay N, Butterworth AE, De Cock KM, Williams BG, Churchyard GJ, et al. Polymorphisms in the tumor necrosis factor- $\alpha$ gene promoter may predispose to severe silicosis in black South African miners. Am J Respir Crit Care Med. 2002;165(5):690-693.

4. Fan HM, Wang Z, Feng FM, Zhang KL, Yuan JX, Sui H, et al. Association of TNF-alpha-238 G/A and 308 G/A gene polymorphism with pulmonary tuberculosis among patients with coal workers' pneumoconiosis. Biomed Environ Sci 2010; 23(2):137-145.

5. Franceschi C, Valensin S, Lescai F, Olivieri F, Licastro F, Grimaldi LM, et al. Neuroinflammation and the genetics of Alzheimer's disease: the search for a pro-inflammatory phenotype. Aging Clin Exp Res. 2001;13(3):163-170.

6. Francis SE, Camp NJ, Dewberry RM, Gunn J, Syrris P, Carter ND, et al. Interleukin-1 receptor antagonist gene polymorphism and coronary artery disease. Circulation. 1999; 99(7):861-866.

7. Gulumian M, Borm PJA, Vallyathan V, Castranova V, Donaldson K, Nelson G, et al. Mechanistically identified suitable biomarkers of exposure, effect, and susceptibility for silicosis and Coal Worker's Pneumoconiosis: A comprehensive review. J Toxicol Environ Health B Crit Rev. 2006; 9(5):357-395. 
8. Huang SL, Su CH, Chang SC. Tumor necrosis factor- $\alpha$ gene polymorphism in chronic bronchitis. Am J Respir Crit Care Med. 1997;156(5):1436-1439.

9. Jiang PR, Cao Z, Qiu ZL, Pan JW, Zhang N, Wu YF. Plasma levels of TNF- $\alpha$ and MMP-9 in patients with silicosis. Eur Rev Med Pharmacol Sci. 2015;19(9):1716-1720.

10. Jonth AC, Silveira L, Fingerlin TE, Sato H, Luby JC, Welsh KI, et al. TGF- $\beta 1$ variants in chronic beryllium disease and sarcoidosis. J Immunol. 2007;179(6):4255-4262. doi:10.4049/jimmunol.179.6.4255.

11. Jorna THJM, Schins RPF, Lenaerts L, Derhaag TJJM, Wouters EFM, Borm PJA. Airflow obstruction and monocyte TNF release in coal workers. Exp Lung Res. 1994;20(5):421-431.

12. Kim KA, Lim Y, Kim JH, Kim EK, Chang HS, Park YM, et al. Potential biomarker of coal workers' pneumoconiosis. Toxicol Lett. 1999; 108:297-302.

13. Kim KA, Cho YY, Cho JS, Yang KH, Lee WK, Lee KH, Kim YS, Lim $Y$. Tumor necrosis factor- $\alpha$ gene promoter polymorphism in coal workers' pneumoconiosis. Mol Cell Biol. 2002;234/235(1):205-209.

14. Kurniawidjaja LM. Silicosis and its progress influenced by genetic variation on TNF-alpha locus-308, TNF-alpha and IL-10 cytokine on cement factory workers in Indonesia. Pak J Biol Sci. 2014;17:419-423.

15. Lassalle P, Gosset P, Arets C, Fournier E, Lafitte JJ, Degreef JM, et al. Abnormal secretion of interleukin-1 and tumor necrosis factor alpha by alveolar macrophages in coal workers' pneumoconiosis: comparison between simple pneumoconiosis and progressive massive fibrosis. Exp Lung Res. 1990;16(1):73-80.

16. Lee JS, Shin JH, Lee JO, Lee KM, Kim JH, Choi BS. Serum levels of interleukin-8 and tumor necrosis factor-alpha in coal workers pneumoconiosis: One-year follow-up study. Saf Health Work. 2010;1(1):69-79.

17. Li J, Hao CF, Yao W, Yun YX, Gao B, Wang YX. A meta analysis of susceptibility to pneumoconiosis and polymorphism of tumor necrosis factor- $\alpha 308$ and 238 locus. Zhonghua Yu Fang Yi Xue Za Zhi. 2011;45(6):547-552.

18. Makamure MT, Reddy P, Chutturgoon A, Naidoo RN, Menta G Batterman $S$, et al. Tumour necrosis factor $\alpha$ polymorphism (TNF$308 \alpha \mathrm{G} / \mathrm{A}$ ) in association with asthma related phenotypes and air pollutants among children in KwaZulu-Natal. Asian Pac J Allergy Immunol. 2016;34:217-222.

19. Morgan WK, Seaton A. Occupational lung diseases. WB Saunders Co. 1975;149-210.

20. Mukhopadhyay S, Hoidal JR, Mukherjee TK. Role of TNF alpha in pulmonary pathophysiology. Respir Res. 2006;11:7-125.

21. Nadif R, Jedlicka A, Mintz M, Bertrand JP, Kleeberger S, Kauffmann F. Effect of TNF and LTA polymorphisms on biological markers of response to oxidative stimuli in coal miners: a model of geneenvironment interaction. J Med Genet. 2003;40:96-103. doi:10.1136/ jmg.40.2.96.

22. Ohtsuka T, Yamakage A, Yamazaki S. The polymorphism of transforming growth factor- $\beta 1$ gene in Japanese patients with systemic sclerosis. British J Dermatol. 2002;147(3):458-463.
23. Ollier WER. Cytokine genes and disease susceptibility. Cytokine. 2004;28:174-178

24. Schins RPF, Borm PJA. Plasma levels of soluble tumour necrosis factor receptors are increased in coal miners with pneumoconiosis. Eur Respir J. 1995;8:1658-1663.

25. Schins RPF, Borm PJA. Mechanisms and mediators in coal dust induced toxicity: a review. Ann Occup Hyg. 1999;43(1):7-33. doi:10.1093/ annhyg/43.1.7.

26. Strober W. Depletion of monocytes/macrophages from mononuclear cells using adherence method. In: Colligan JE, Kruisbeck M, Margulies DH, Shevach EM, Strober, W, Coico R, editors. Current Protocols in Immunology. USA: John Wiley \&Sons Inc.; USA 1994. Section:7.1.3.

27. Turkey Herd Coal Enterprise. Turkey hard Coal Enterprise Annual Activity Report 2015. http://www.tki.gov.tr.

28. Vanhee D, Gosset P, Boitelle A, Wallaert B, Tonnel AB. Cytokines and cytokine network in silicosis and coal workers' pneumoconiosis. Eur Respir J. 1995;8:834-842.

29. Wang XT, Ohtsuka Y, Kimura K, Muroi M, Ishida T, Saito J, Munakata M. Antithetical effect of tumor necrosis factor- $\alpha$ gene polymorphism on coal workers' pneumoconiosis (CWP). Am J Ind Med. 2005;48:24-29.

30. Wang YW, Lan JY, Yang LY, Wang De J, Kuang J. TNF- $\alpha$ and IL-1RA polymorphisms and silicosis susceptibility in Chinese workers exposed to silica particles: a-case control study. Biomed Environ Sci. 2012;25(5):517-525.

31. Whyte M, Hubbard R, Meliconi R, Whidborne M, Eaton V, Bingle C, et al. Increased risk of fibrosing alveolitis associated with interleukin-1 receptor antagonist and tumor necrosis factor- $\alpha$ gene polymorphisms. Am J Respir Crit Care Med. 2000;162(2):755-758.

32. Witte JS, Palmer U, O'Connor RD, Hopkins PJ, Hall LM. Relation between tumor necrosis factor polymorphism TNFa-308 and risk of asthma. Eur. J Hum Genet. 2002;10:82-85.

33. Yang YH, Liu YQ, Zhang L, Li H, Li XB, Ouyang Q, et al. Genetic polymorphisms of the TNF- $\alpha-308 \mathrm{G} / \mathrm{A}$ are associated with metabolic syndrome in asthmatic patients from Hebei province, China. Int J Clin Exp Pathol. 2015;8(10):13739-13746.

34. Yucesoy B, Vallyathan V, Landsittel DP, Sharp DS, Weston A, Burleson GR, et al. Association of tumor necrosis factor- $\alpha$ and interleukin-1 gene polymorphisms with silicosis. Toxicol Applied Pharmacol. 2001;172(1):75-82.

35. Yucesoy B, Peila R, White LR, Wu KM, Johnson VJ, Kashon ML, et al. Association of interleukin-1 gene polymorphisms with dementia in a community-based sample: the Honolulu-Asia aging study. Neurobiol Aging. 2005;27(2):211-217.

36. Zhai R, Jetten M, Schins RPF, Franssen H, Borm PJA. Polymorphisms in the promoter of the tumor necrosis factor- $\alpha$ gene in coal miners. Am J Ind Med. 1998;34(4):318-324.

37.Zhang Y, Wang F, Lan Y, Zhou D, Ren X, Zhao L, et al. Roles of microRNA-146a and microRNA-181b in regulating the secretion of tumor necrosis factor- $\alpha$ and interleukin $1-\beta$ in silicon dioxide-induced NR8383 rat macrophages. Mol Med Rep. 2015;12(4):5587-5593. 